\title{
Assessing Institutional Support to Online Education at Tertiary Level in Bangladesh Coping with Covid-19 Pandemic: An Empirical Study
}

\author{
Mohammad Nur Ullah, Bikram Biswas², Md. Mamun Miah³ \\ 1 , \\ ${ }^{1}$ Department of Public Administration, Bangladesh University of Professionals, Mirpur \\ Cantonment, Dhaka-1216, Email: nurullahniaz@gmail.com \\ ${ }^{2}$ Department of Educational Administration, Noakhali Science and Technology \\ University, Noakhali-3814, Bangladesh. \\ 3Department of Statistics, Noakhali Science and Technology University, Noakhali-3814, \\ Bangladesh.
}

E-mail : bikramju1020@gmail.com, bikram.ea@nstu.edu.bd, nurullahniaz@gmail.com, mamun.stat@nstu.edu.bd

\begin{abstract}
Institutional support and quality education are linked in a significant way. During Covid-19, institutional support is critical to closing the huge academic gap that has emerged as physical academic practices have been moved to a virtual education system using technology. This research aims to assess institutional support for online education in Bangladesh during the Covid-19 pandemic. This analysis is focused on the three main elements of the Adapted Model of Institutional Support (AMIS) of Bond et al, 2007, and the Institutional Support Model (ISM) of Valverde and Rodriguez, 2002, namely Financial Support (FS), Technical Support (TS), and Mentoring Support (MS). According to the findings, a few universities in Bangladesh have provided average support for continuing online education, while others have just started taking online classes. Several problems have been discovered, such as the lack of dedicated software for conducting online academic activities, lack of training and grooming, lack of mentoring, poor internet access, lack of smartphones, high internet package rates, and so on. This study concludes with some policy recommendations for a smooth online education system in Bangladesh.
\end{abstract}

Keywords: Assessment, Institutional Support, Online Education, Tertiary Education, Covid19, Bangladesh

\section{Introduction:}

The Corona Virus has wreaked havoc on education, as well as other aspects of the state, such as Bangladesh. Following the emergence of the coronavirus pandemic in 2020, Bangladesh's education system, like that of most other nations around the world, has undergone significant changes as a result of the widespread adoption of online learning (Dhaka Tribune, 31st December, 2020). The quality and popularity of online education vary by country and institution. Learning and teaching styles, personal motivation, and infrastructure are all important factors in ensuring a smooth online teaching experience (Eom et al., 2006). Bangladesh's public and private universities, colleges, and schools have shifted their classes to online. According to a recent survey, while $40 \%$ of students are taking online classes, nearly half of them are unable to do so due to a lack of devices. However, most of them $(70 \%)$ are 
from private universities. Students also feel the online courses are somewhat doubtful in terms of viability and efficacy (Islam et al., 2020).

In developing countries like Bangladesh, the main argument against online classes is a lack of a reliable internet connection (Islam, et al, 2020). Even though they can attend classes, the experience is inefficient because they have difficulty following the lecture because the network is constantly down, preventing them from communicating effectively with the teachers. Because of the poor internet connection, this problem becomes even worse for students who visited or lived in the village during the Pandemic (Al-Amin et al, 2021). Because the majority of students do not own a laptop or computer, online classes discourage class participation. Assignments and tasks cannot be completed on a smartphone. Students are unable to use cyber cafes or repair malfunctioning computers in this situation. Students also stated that online classes are not the same as in-person classes because they are less engaging. When it comes to administering online examinations, quizzes, presentations, or any other type of graded activity through an online platform, the interest grows even more.

Although educational institutions are providing various supports such as television, radio, and social media platforms to reach students from various areas, the household income and expenditure survey 2020 revealed that approximately 12.70 percent of poor families do not own a mobile phone, even though students need at least a Smartphone and a stable internet connection to attend online classes (Tariq and Fami, 2020). In an online seminar hosted by the Center on Budget and Policy, prominent educators shared their perspectives on online education. According to the speakers, holding online classes for 7.5 lakh students will cost around Tk. 10,000 crores. He requested a reduction in internet usage charges, which he believes the government can arrange (The Business Standard, 2020). The government of Bangladesh, the university grant commission, educational institutions, and other non-governmental organizations have all taken steps to help Bangladesh cope with the pandemic and address the country's uncountable educational losses. Educational institutions are attempting to reach out to students via various mediums, including television, radio, and social media platforms such as Facebook, Zoom, Google classroom, Google meet, and others, to assist them in continuing their education (Tariq, and Fami, 2020).

This paper's main goal is to assess institutional support for online education at the tertiary level in Bangladesh as it deals with the covid-19 pandemic. This study is based on a descriptive analysis of social research, in which both qualitative and quantitative data were used to satisfy the study's objectives.

\section{Research Design and Methodology:}

This study is purely descriptive. This empirical analysis was performed using both qualitative and quantitative approaches. For this analysis, data was gathered from both primary and secondary sources. Primary data was collected from public and private university teachers and students through an online survey that included both structured and unstructured questions. Secondary data was gathered from a variety of sources, including books, journals, blogs, web sources, and newspapers. The research used five Likert scale instruments to determine institutional support for online education at the tertiary level in Bangladesh. Bond et al., 2007's Adapted Model of Institutional Support (AMIS) and Valverde and Rodriguez's 2002's Institutional Support Model (ISM) models lead this research to its target. A purposive sampling technique was used to perform this analysis. The sample for this analysis is 320 participants. 
Teachers from various public and private universities in Bangladesh, as well as students from those universities, were the participants.

For this study, a mixed questionnaire was developed based on the Adapted Model of Institutional Support (AMIS) of Bond et al, 2007, and the Institutional Support Model (ISM) of Valverde and Rodriguez, 2002. There are four basic parts of the questionnaire containing personal information, perceptional information, institutional support information, and some general statements of the respondents. Five-point Likert scale Strongly agree (SA), Agree (A), Moderate (M), Disagree (D), Strongly Disagree (SD), YN (Yes, No), and open-ended questions are used to fulfill the study objectives. It was an online survey for collecting primary data, so the questionnaire was in Google Form. SPSS, MS Word, and MS Excel were used to tabulate, process, and analyze the data collected from various respondents through an online survey. The data was analyzed using both nominal and ordinal measurements.

\section{Theoretical Framework:}

We looked at two key models to determine institutional support. Bond et al. developed the Adapted Model of Institutional Support (AMIS) in 2007. Financial support, emotional and moral support, mentoring, professional socialization, academic advising, and technical support were all used to create the model (Bond et al, 2015). Another is the Institutional Support Model (ISM), which includes financial, emotional, and technical support. The table below summarizes the underlying concepts of these two models:

\begin{tabular}{|c|c|c|c|}
\hline \multicolumn{2}{|c|}{$\begin{array}{l}\text { Adapted Model of Institutional Support } \\
\text { (AMIS) }\end{array}$} & \multicolumn{2}{|c|}{$\begin{array}{l}\text { Institutional Support Model (ISM) } \\
\text { (Valverde and Rodriguez, 2002) }\end{array}$} \\
\hline Items & Description & Items & Description \\
\hline $\begin{array}{l}\text { Financial } \\
\text { Support }\end{array}$ & Money to pay for tuition & $\begin{array}{l}\text { Financial } \\
\text { Support }\end{array}$ & $\begin{array}{l}\text { Loans, fellowship, } \\
\text { Assistance for research }\end{array}$ \\
\hline $\begin{array}{l}\text { Emotional and } \\
\text { Moral Support }\end{array}$ & $\begin{array}{l}\text { Relationship with individual } \\
\text { faculty, family and students }\end{array}$ & $\begin{array}{l}\text { Emotional or } \\
\text { Moral Support }\end{array}$ & $\begin{array}{l}\text { Cohort support to each other, } \\
\text { cultural and social activities, } \\
\text { individual bonds with faculty } \\
\text { and staff. }\end{array}$ \\
\hline Mentoring & $\begin{array}{l}\text { Long-term relationship with } \\
\text { a role model, usually a } \\
\text { cultural match }\end{array}$ & Mentorship & Moving Students along \\
\hline $\begin{array}{l}\text { Technical } \\
\text { Support }\end{array}$ & $\begin{array}{l}\text { Access to and assistance } \\
\text { with computers, equipment } \\
\text { and skills needed to conduct } \\
\text { research and study }\end{array}$ & \multirow[t]{3}{*}{ Technical } & \multirow[t]{3}{*}{$\begin{array}{l}\text { Research design, statistics, } \\
\text { computer usage, laboratory } \\
\text { availability, equipment } \\
\text { availability. }\end{array}$} \\
\hline $\begin{array}{l}\text { Academic } \\
\text { Advising }\end{array}$ & $\begin{array}{l}\text { Guidance for plan of study } \\
\text { and specific courses }\end{array}$ & & \\
\hline $\begin{array}{l}\text { Professional } \\
\text { Socialization }\end{array}$ & $\begin{array}{l}\text { Activities to enhance skills } \\
\text { and abilities as a } \\
\text { professionals }\end{array}$ & & \\
\hline
\end{tabular}

Source: Compiled by the authors based on Bond et al, 2015 and Valverde and Rodriguez, 2002

Following the analysis of the above two models, this study developed a model that includes the three items listed below to assess institutional support for online education in Bangladesh at the tertiary level; 


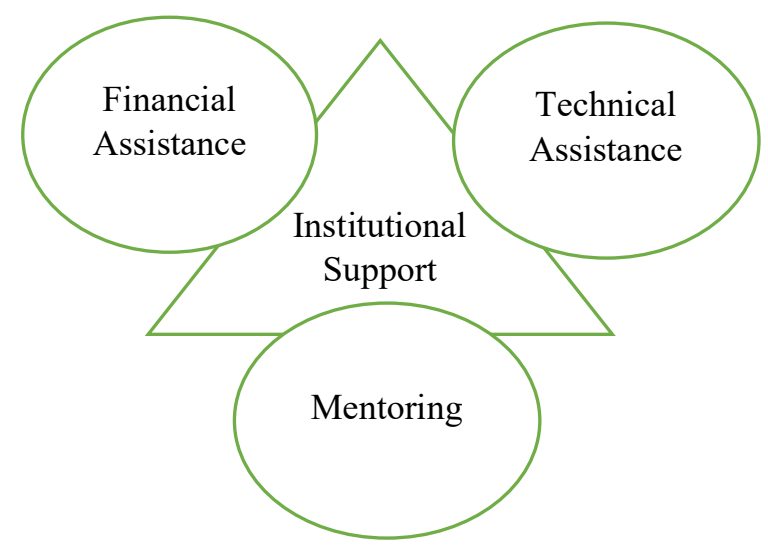

Figure 01: Model Developed by the Authors

\section{Literature Review:}

\subsection{Reviewing Related Literature and Finding the Research Gap:}

Schrum \& Hong (2002) reports that Students may lack the necessary skills and strategies to meet the demands of online teaching and learning. Educators said that tools, technology experience, learning preference, study habits and skills, lifestyle, and personal characteristics are some important dimensions that influence smooth and effective online teaching and learning, according to the study.

Bangert (2006), identified that for smooth and efficient online learning, teacher-student interaction, reciprocal student collaboration, active learning, and time on task are all important factors. Without a doubt, students' psychological problems have an impact on their education. But Goto \& Martin (2009) mentioned that the instructors and authorities rarely address these difficulties. Family members, peers, and fellow students are the most influential psychological factors.

Bennett \& Monds (2008) and Gorsky \& Blau (2009), examine that Communication and social support were discovered to be the most important factors in online teaching, with the vigorous delivery of the teacher plays a key role. Business schools have been identified as the forerunners in launching online courses that provide students with more integrated and flexible learning opportunities.

According to Khan et al., (2020), after an initial period of institutional closure and class suspension as the COVID-19 pandemic continued, public universities in Bangladesh began to take preliminary steps toward online classes. Teachers were forced to conduct emergency remote teaching without much planning. In light of this, the purpose of this research was to learn more about teachers' views on online teaching and learning in the context of the pandemic. The study's goal was to identify the significant challenges that teachers faced as a result of the sudden shift to remote online teaching. Additionally, the goal was to get their feedback on how to make online instruction run smoothly.

Emon et al., (2020), examines, over 40 million students in Bangladesh have dropped out of school before the epidemic subsides. Aside from this universal disruption, out-of-school learning deprivation varies depending on the socioeconomic status of the general public, their access to technology, parental capacities, and other factors. During the pandemic, most 
countries are using online or satellite television platforms to provide education, but this is insufficient to meet the varying levels. Although developed countries (first and second world) are making significant progress with online education, the rest of the world continues to struggle (third-world countries).

According to Dong, 2020, foreign students are forced to turn to online instruction for academic study due to the global COVID-19 pandemic. This study shows a series of challenges facing both Chinese teachers and Bangladeshi students, based on a longitudinal ethnography with a cohort of Bangladeshi students who study in an English-medium degree program in software engineering. Due to the weak network infrastructure in Bangladesh and the time difference between China and Bangladesh, Chinese teachers felt they had no control over their students' class participation; Bangladeshi students felt disappointed in accessing Chinese-mediated online teaching applications due to their lack of Chinese proficiency; and their inability to run the applications due to their inaccessibility.

According to Internet World Stats, there will be 96,199,000 internet users in Bangladesh by May 2020, representing a 58.4 percent penetration of the total population. According to statistics, the country's internet penetration rate is low, which may be a stumbling block for students considering online education. Uneven possession and access to technology, such as smartphones or laptops, as well as affordability of technology, such as buying the internet, pose major threats and gaps to students' continued participation in online education (Indiana University, 2018).

Jasim, (2020) and Sujan, (2020), said that since the beginning of the COVID-19 pandemic, when the symptoms lasted longer, $60 \%$ of universities began to continue their academic activities online, and the UGC, Bangladesh's regulatory body for universities, urged holding classes online. According to the University Grants Commission, 63 universities in Bangladesh, including seven public universities, offer online courses with 60-70 percent student attendance. This low rate of attendance is concerning for online learning.

Tabassum et al, 2021 states that about $88.5 \%$ of participants took online classes at the time of the epidemic, and most $(91.3 \%)$ were at home. They may face some problems in their online classes, and poor Internet connectivity (69.31\%) and lack of managerial support $(19.13 \%)$ are the main problems. Very few $(1.4 \%)$ believe that this process does not help alleviate educational inequalities.

Al-amin et al., 2021 states that more than 844 students from various Bangladeshi universities prepare, participate and analyze online classroom activities during epidemics. The results showed a lack of preparation, participation, and less space for classroom activities through online learning. The instability of the Internet and electricity through online platforms, problems of attention, comprehension lessons are the main barriers to online learning in developing countries.

\subsection{Research Gap:}

After reviewing the above-mentioned literature, we discovered that they discussed more or less online education in Bangladesh, its causes and consequences, the factors involved in online education, and the challenges of online education, but the most important area that has yet to be researched is institutional support for online education and its level of satisfaction among teachers and students. In light of this, the purpose of this research is to look into institutional support for online education at the tertiary level in Bangladesh as the country grapples with the covid-19 pandemic. 


\subsection{Contextual Brief of Online Education during Covid-19:}

Due to the fear of a COVID-19 pandemic, academic institutions in Bangladesh have been closed for the foreseeable future in March 2020 (Moralista \& Oducado, 2020). The majority of students, as well as other people involved in the education sector, were negatively affected by the closure of academic institutions. Many countries around the world have begun to implement online education systems and are continuing to do so to close the educational gap (Rahman, 2020). However, most of the of the students at the university level of Bangladesh have a positive perception of mobile learning that is related to technical adaptation of online education (Bikram et al., 2020). On the other side, many students and parents are opposed to the idea of resuming classes through online platforms. Their main points of contention were a lack of consistent, stable internet connections, a lack of appropriate devices, the cost of data, the financial situation of their families, mental stress, and others. On the other hand, a small group of students and professors from various universities argued in favor of using e-learning methods (Moralista \& Oducado, 2020). BioTED, a new training and research initiative, conducted a study at 42 private and public universities, finding that only $23 \%$ of students were in favor of taking online classes in this scenario, while the remaining $77 \%$ were against it. Only 55.3 percent of students have a laptop, PC, or tablet with which to take an online course. It shows that 44.7 percent of students are unable to attend online classes due to logistical issues. The most important factor for online classes is internet connectivity, and according to our poll, 55 percent of students do not have enough internet connections to continue their education online. They also discovered that $40 \%$ of students are now taking online courses, with the majority (70\%) coming from private universities (Bangla tribune, 2020). The University Grant Commission of Bangladesh (UGCB) has issued guidelines for taking online courses at private universities. Private university semester courses and examinations can now be taken online, according to the authority. Universities, on the other hand, are not permitted to begin new semester activities before July 2020. Furthermore, private universities have been requesting permission to accept students in different forms since March. They are also permitted to take both classes and examinations online, according to the authority's guidelines. The practical test of scientific subjects, on the other hand, cannot be taken in any manner online in this case. Furthermore, when taking online exams, maximum transparency is required. The university will be able to organize the remaining activities in the next semester if at least $60 \%$ of the classes were finished before the Pandemic (Sujan, 2020). However, another group of students concerned about the length of the semester supports online classes but opposes online examinations. Online connectivity, according to faculty, does not necessitate a lot of planning. Some universities have aided students by purchasing mobile internet packages for them, eliminating the need for them to go outside. Given the current state of affairs, online classes may become commonplace. It's critical to get it right the first time and ensure that no student group is left behind (Megha, 2020).

\subsection{Conceptual Brief of Institutional Support:}

The environment of the institution and student engagement is influenced by institutional support (Battistich et al., 1995). In this context, institutional support refers to active organizational encouragements in the form of policies, laws, monetary and non-monetary aid that motivate students and teachers to carry out their duties in a highly efficient and productive manner (Al-Enazi, 2016; Saint et al., 2003). It refers to the resources, opportunities, privileges, and services provided by institutions to students, teachers, and other employees (StantonSalazar, 2011). Institutional support connects stakeholders to a network of resources, expertise, and emotional support that allows them to navigate the institution more effectively and successfully. The cultural landscape of a student's life influences institutional support. The 
learning environment has an impact on culturally specific traits such as interests, attitudes, and skills (Gottfredson, 2002, 1996). For ethnically diverse students, institutional support affects engagement and achievement. (Bottiani, Bradshaw, \& Mendelson, 2016; Cornell, Shukla, \& Konold, 2016; Kotok, Ikoma, \& Bodovski, 2016). Students benefit from institutional support because they have a network to help them overcome problems and obstacles that affect their self-esteem and psychosocial well-being (Stanton-Salazar, 2011).

\subsection{Institutional Supports to Online Education in Bangladesh:}

The pandemic has impacted the education of about four crore students in the country, from primary to university level, as they are unable to attend in-person classes after all institutions were closed on March 17 to combat Covid-19 (Alamgir, 2020). In May, the country's 46 public universities began offering online academic courses to more than 500,000 students, including a large number of needy students from rural areas. However, many public university students are said to be without smartphones due to a lack of financial resources, preventing them from participating in online courses (Panday, 2020). Teachers and students are not adequately prepared for distance learning. In light of this, the government, the UGC, and educational institutions all provided various forms of assistance for continuing online education. Universities, both public and private, are calling for more affordable mobile internet packages for their students. In a letter to Post and Telecommunications Minister Mustafa Jabbar on June 15, the Association of Private Universities of Bangladesh (APUB) requested special internet packages for private university students. At a meeting with the University Grants Commission on June 25, the vice-chancellors of most public universities made a similar request (Alamgir, 2020).

The University Grants Commission (UGC), the nation's apex regulatory body for higher education, released letters to 43 public universities on Aug. 6 requesting lists of poor students who do not have smartphones and need financial assistance. The UGC requested grants or lowinterest loans for students who needed to purchase smartphones to take online classes. In the budget for the fiscal year 2020-2021, the government announced that Tk66,400 crore would be allocated to education. This was equivalent to 11.7 percent of total spending and 2.1 percent of GDP (Abdullah, 2021). Soft loans, stipends, online packages, reduced semester fees, and a variety of other benefits are available to students at a variety of private and public universities. Other programs have been offered, such as online education training, dedicated software for online classes, examinations, and tests, in order to close any gaps that may arise.

\section{Results and Findings:}

\subsection{Demographic Data of the Respondents:}

Here, demographic data includes three variables i.e. Gender. Age and University. In table no. 02 , respondents are classified by sex, age, and university. In terms of gender, $164(51.3 \%)$ of respondents were male and $156(48.8 \%)$ were female. Both are dominating equally in this study. Regarding age, 30 (9.45) respondents aged <16-20. $278(86.9 \%)$ were aged between 21-25. And the rest, $12(3.8 \%)$ were in the category of 26-30. Regarding their university, most of the respondents, $214(66.67 \%)$ were from public universities. And the rest $106(33.33 \%)$ were from private universities.

Table No. 02: Demographic Background of the respondents

\begin{tabular}{|c|c|c|c|}
\hline Variable & Categories & Frequency & Percentages \\
\hline & Male & 164 & $51.3 \%$ \\
\hline
\end{tabular}




\begin{tabular}{|c|c|c|c|}
\hline \multirow{2}{*}{ Gender } & Female & 156 & $48.8 \%$ \\
\hline \multirow{3}{*}{ Age } & Total (N) & $\mathbf{N}=\mathbf{3 2 0}$ & $\mathbf{1 0 0} \%$ \\
\hline & $<16-20$ & 30 & $9.4 \%$ \\
\hline \multirow{3}{*}{ University } & $21-25$ & 278 & $86.9 \%$ \\
\hline & $26-30$ & 12 & $3.8 \%$ \\
\hline & Total (N) & $\mathbf{N}=\mathbf{3 2 0}$ & $\mathbf{1 0 0 \%}$ \\
\hline & Public & 214 & $66.67 \%$ \\
\hline & Private & 106 & $33.33 \%$ \\
\hline
\end{tabular}

Source: Field Survey

\subsection{Perception towards Online Classes:}

This study asked multiple questions to find out how respondents felt about online classes during Covid-19. Figures 02, 03, and 04, as well as table 03, display the results of the survey. Figure no. 02 depicts the responses to the question, "Are you active in online classes?" The majority of those polled participate in online classes. $308(96.30 \%)$ said they are participating in online classes, while only $12(3.80 \%)$ said they are not. The data on respondents' satisfaction with online classes is shown in Table No. 3. The majority of respondents are only marginally happy with their online education. In this category, there were $148(46.3 \%)$ respondents. 48 respondents (15\%) are satisfied. A significant number of people, $120(37.5 \%)$, are dissatisfied. And four of them were unable to respond. Figure no. 03 shows how respondents reacted to the question, "Do you think online classes are more interactive than physical ones?" Just 36 (11\%) of respondents said online classes are interactive, while $266(83 \%)$ said online classes are not interactive as compared to physical classes. $18(6 \%)$ of respondents don't know whether it's interactive or not. And figure no. 04 categorizes the data about 'Does online classes meet the needs and demands of the quality education'. 244 (76.30\%) respondents said online classes do not meet the needs and demands of quality education while only $42(13.10 \%)$ said online classes meet standards. $34(10.60 \%)$ could not respond.

Figure No. 02: Are you active in online classes

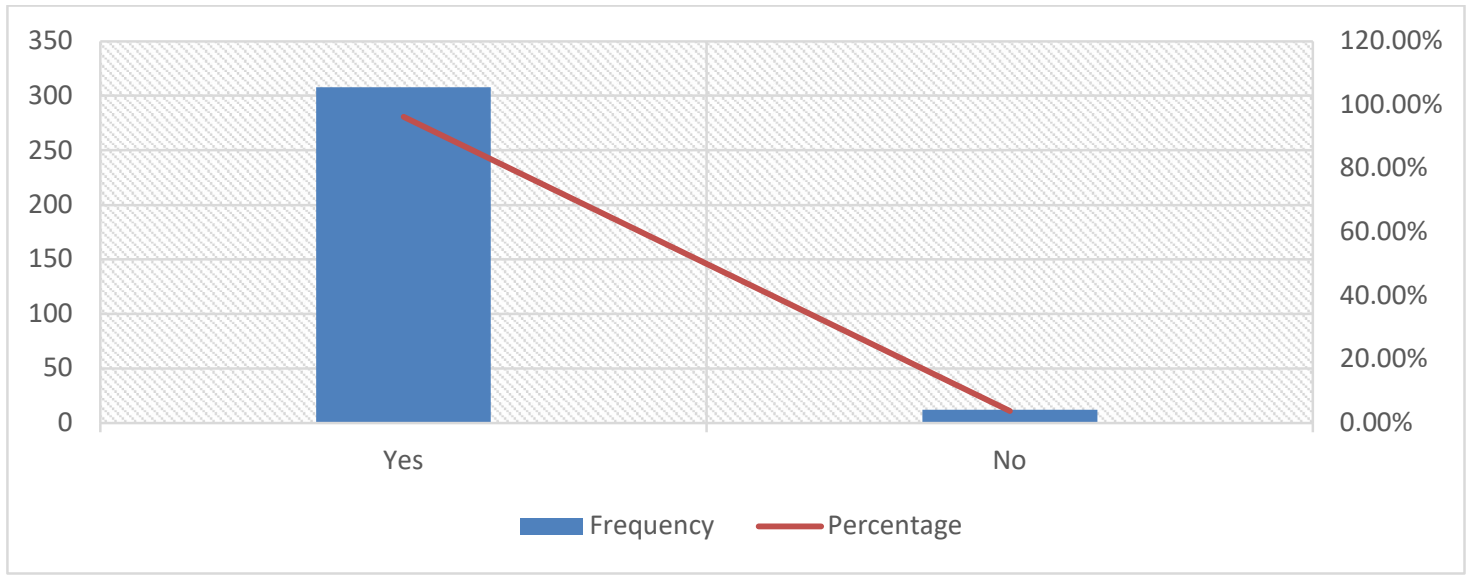

Source: Field Survey 
Table No. 03: Are you satisfied with the online classes?

\begin{tabular}{|l|c|c|c|c|}
\hline Categories & Frequency & Percentage & $\begin{array}{l}\text { Valid } \\
\text { Percent }\end{array}$ & $\begin{array}{l}\text { Cumulative } \\
\text { Percent }\end{array}$ \\
\hline Satisfied & 48 & $15.0 \%$ & $15.0 \%$ & $15.0 \%$ \\
\hline Partially Satisfied & 148 & $46.3 \%$ & $46.3 \%$ & $61.3 \%$ \\
\hline Not Satisfied & 120 & $37.5 \%$ & $37.5 \%$ & $98.8 \%$ \\
\hline No Response & 4 & $1.3 \%$ & $1.3 \%$ & $100 \%$ \\
\hline Total & $\mathbf{N}=\mathbf{3 2 0}$ & $\mathbf{1 0 0 \%}$ & $\mathbf{1 0 0} \%$ & \\
\hline
\end{tabular}

Source: Field Survey

Figure No. 03: Do you think that online classes are interactive than physical one

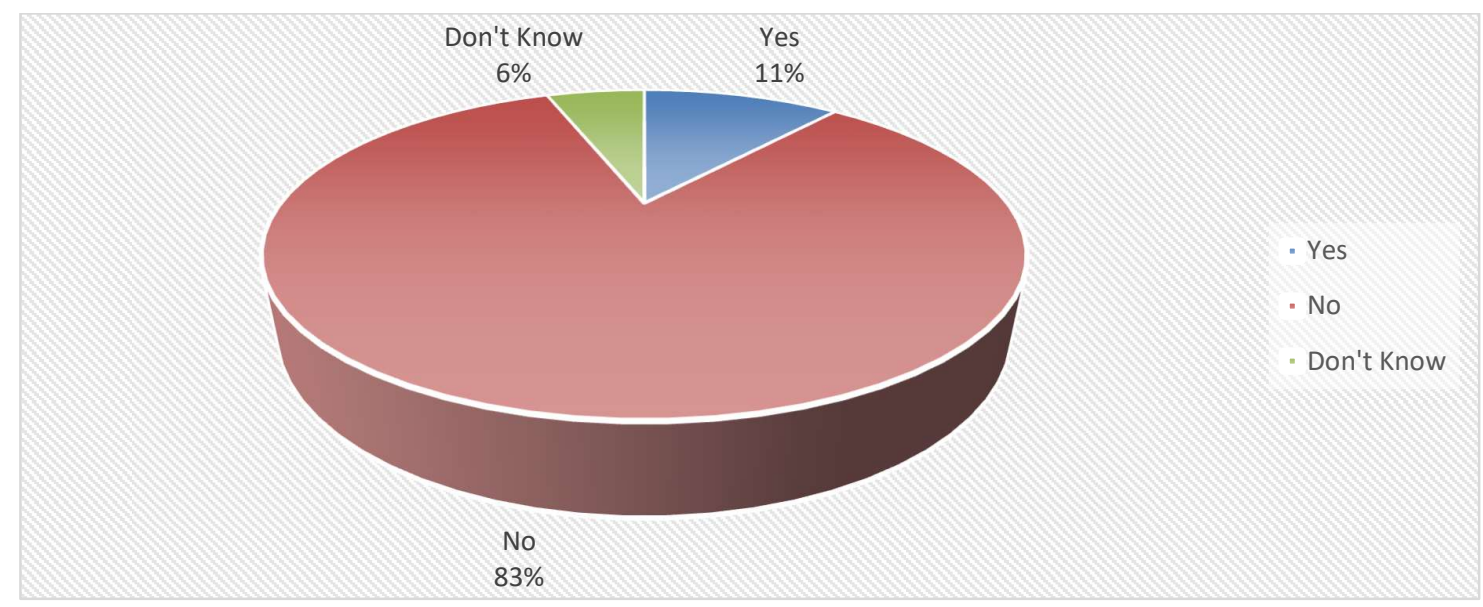

Source: Field Survey

Figure No. 04: Do online classes meet the needs and demands of the quality education

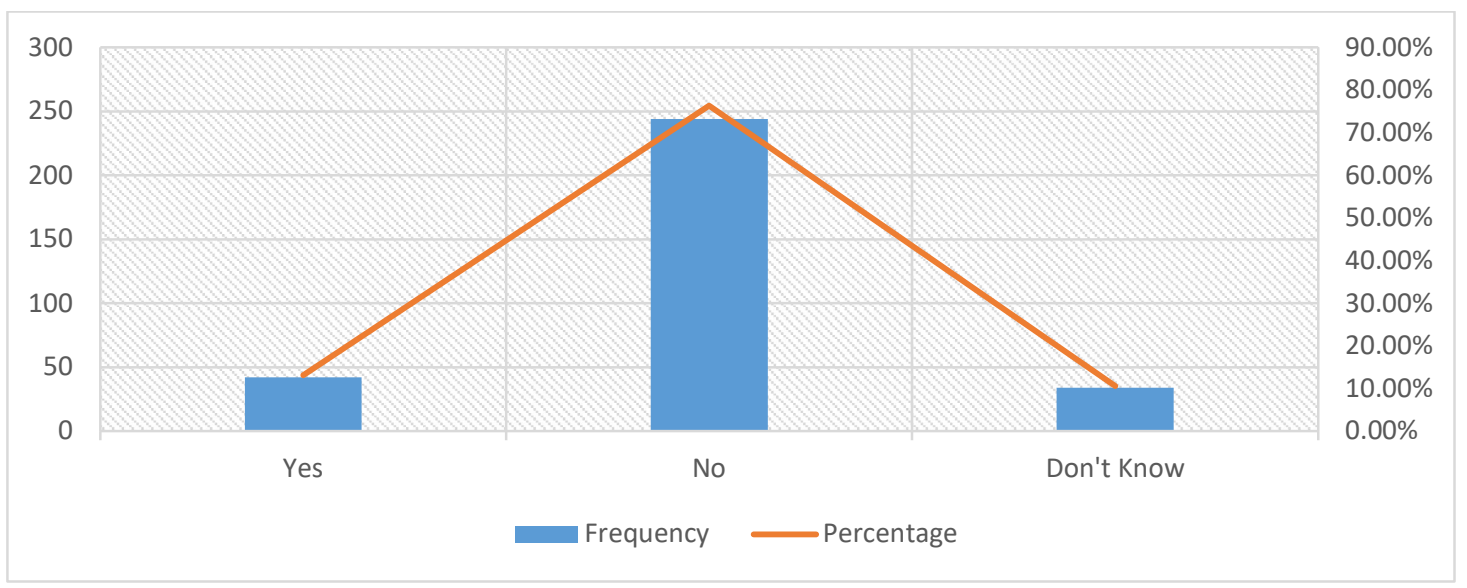

Source: Field Survey 


\subsection{Institutional Support to Online Education}

\subsubsection{General:}

To get general information on online education, two questions were asked in this regard. All the responses are shown in figure no. 05 and table no. 04. Figure no. 05 contains yes-no question like did you get any support from your university for continuing online classes? The majority of the respondents acknowledge the support provided by the universities. 222 $(69.40 \%)$ respondents were in this category. And rest 98 (30.60\%) respondents said they did not get any support from their universities. And table no. 04 shows the responses regarding their satisfaction with the assistance they got from their university. Most of the respondents are partially satisfied. $120(37.5 \%)$ respondents are in this category. $88(27.5 \%)$ are satisfied, $76(23.8 \%)$ are not satisfied with the university support during covid-19. And a great number of the respondents, $36(11.3 \%)$ could not respond.

Figure No. 05: Did you get any support from your university for continuing online classes?

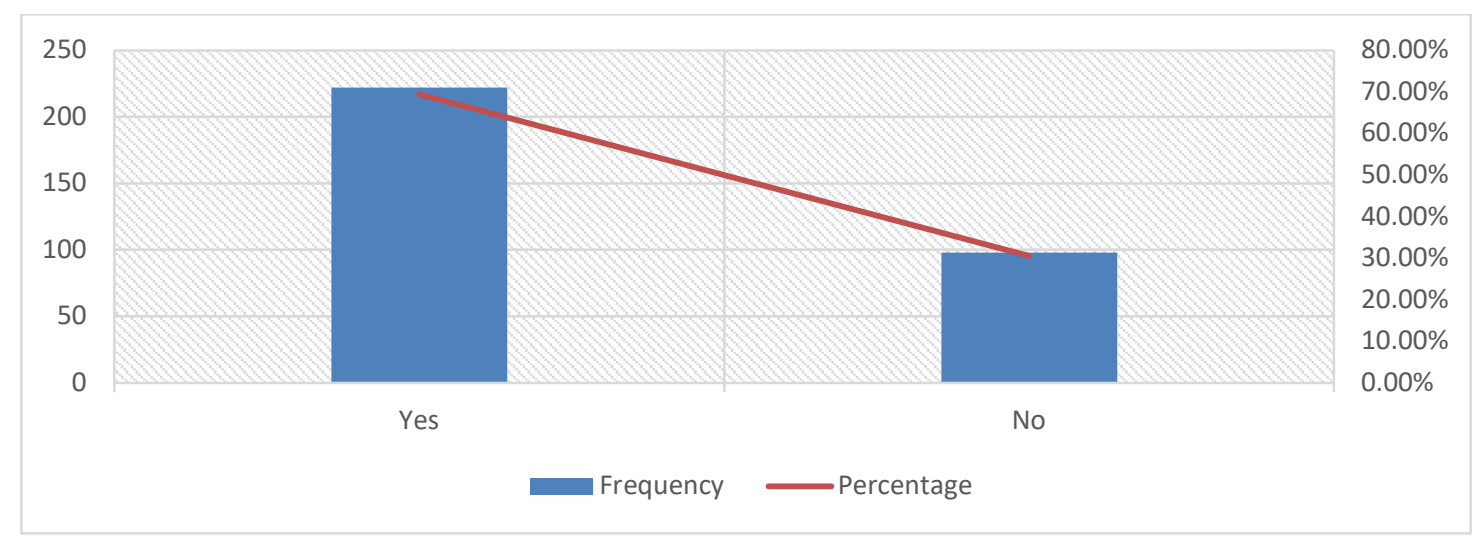

Source: Field Survey

Table No. 04: Are you satisfied with the assistance you got from your university

\begin{tabular}{|l|c|c|c|c|}
\hline Categories & Frequency & Percentage & $\begin{array}{l}\text { Valid } \\
\text { Percent }\end{array}$ & $\begin{array}{l}\text { Cumulative } \\
\text { Percent }\end{array}$ \\
\hline Satisfied & 88 & $27.5 \%$ & $27.5 \%$ & $27.5 \%$ \\
\hline Partially Satisfied & 120 & $37.5 \%$ & $37.5 \%$ & $65 \%$ \\
\hline Not Satisfied & 76 & $23.8 \%$ & $23.8 \%$ & $88.8 \%$ \\
\hline No Response & 36 & $11.3 \%$ & $11.3 \%$ & $100 \%$ \\
\hline Total & $\mathbf{N}=\mathbf{3 2 0}$ & $\mathbf{1 0 0 \%}$ & $\mathbf{1 0 0} \%$ & \\
\hline
\end{tabular}

Source: Field Survey

\subsubsection{Financial Assistance}

Providing financial assistance to students to pay tuition fees and living expenses through a hybrid scheme of loans and grants, in accordance with the general idea that tertiary education uses public funds in a manner that promotes its contribution to society and the economy (OECD, 2008). Lavy (2002) discovers a connection between financial support and teacher success rewards and student achievement. To assess the financial assistance to online education 
at the tertiary level, this study asked the respondents three basic questions, answer of those questions are shown in three separate categories i.e. Yes, No, and Don't Know contained by table no. 05. The responses regarding 'Do your university provide financial assistance for distress and meritorious students?' are shown in the table. Most of the respondents said that their university provides financial assistance for distress and meritorious students. $266(83.1 \%)$ respondents are included in this category. 36(11.3\%) said their university did not provide such financial allocation. And the rest could not respond. Regarding 'Have your university Reduced/ compromised in semester fees?' $144(45 \%)$ said their university reduced semester fees during covid-19. A large number of the respondents, 130 (40.6\%) said their university did not reduce semester fees. $46(14.3 \%)$ respondents could not respond in this regard. Regarding 'Have your university Provided Loans/ Monetary Assistance for Buying Smartphone/ Laptop?', 165 (51.6\%) said their university Provided Loans/ Monetary Assistance for Buying Smartphone/ Laptop. $121(37.8 \%)$ respondents have given negative responses in this regard. A great number, $34(10.6 \%)$ could not respond.

Table No. 05: Financial Assistance Provided by Universities

\begin{tabular}{|l|l|l|l|l|l|l|l|}
\hline \multicolumn{1}{|c|}{ Questions } & \multicolumn{2}{c|}{ Yes } & \multicolumn{3}{c|}{ No } & \multicolumn{2}{c|}{ Don't Know } \\
\cline { 3 - 9 } & $\mathbf{N}$ & $\%$ & $\mathbf{N}$ & $\mathbf{\%}$ & $\mathbf{N}$ & $\%$ \\
\hline $\begin{array}{l}\text { Does your university provide financial } \\
\text { assistance for distress and meritorious } \\
\text { students? }\end{array}$ & 266 & $83.1 \%$ & 36 & $11.3 \%$ & 18 & $5.7 \%$ \\
\hline $\begin{array}{l}\text { Have your university Reduced/ } \\
\text { compromised in semester fees? }\end{array}$ & 144 & $45 \%$ & 130 & $40.6 \%$ & 46 & $14.3 \%$ \\
\hline $\begin{array}{l}\text { Has your university Provided Loans/ } \\
\text { Monetary Assistance for Buying } \\
\text { Smartphones/Laptop? }\end{array}$ & 165 & $51.6 \%$ & 121 & $37.8 \%$ & 34 & $10.6 \%$ \\
\hline
\end{tabular}

Source: Field Survey

\subsubsection{Technical Assistance}

Both teachers and students need technical assistance (Sirkemaa, 2001). Teachers need technical assistance to ensure that they have the resources and skills required to integrate technology into their classroom practices. Technical assistance aids students in acquiring the expertise and skills they need to meet their specific curriculum requirements (Valdez et al., 2004). Installation, operation, maintenance, network administration, and security are all examples of technical support (Sife et al., 2007). To evaluate the technical assistance provided by the universities of Bangladesh during the corona pandemic, this study asked four questions, opinions of the respondents are categorized in the following figure no. 06, 07 and 08 and table no. 06. In figure no. 06, regarding 'Does your university have dedicated software for online classes, exams, and assessments', 201 (62.8\%) respondents said they don't have any dedicated software. 103 (32.18\%) respondents have dedicated software support of their universities. 5\% do not know whether they have or not. Figure No. 07 contains responses regarding 'Does your university have online library facilities'. 166 (52\%) respondents said that their universities do not have online library facilities. On the other hand, $102(32 \%)$ said they have online library facilities provided by their universities. And a large number, 52 (16\%) do not know about it. Regarding 'Did you get any training regarding online education from your university', figure no.08 shows, most of the respondents said they did not get any training for online classes or any other grooming sessions. $246(76.8 \%)$ respondents are in this category. And the rest 74 $(23.1 \%)$ said that they got the relevant training and grooming from their universities. And table 
No. 06 contains the responses regarding 'What are the tools your university encourages to use for online education like Zoom, Google mate, Google classroom, LMS etc'. Most of the respondents are using zoom software for continuing their online classes. $302(94.2 \%)$ respondents are in this category. $4(1.2 \%)$ respondents said about Google mate, $11(3.4 \%)$ respondents said about Google classroom and other tools are used by the rest $5(1.5 \%)$.

Figure No. 06: Does your university have dedicated software for online classes, exams, and assessments?

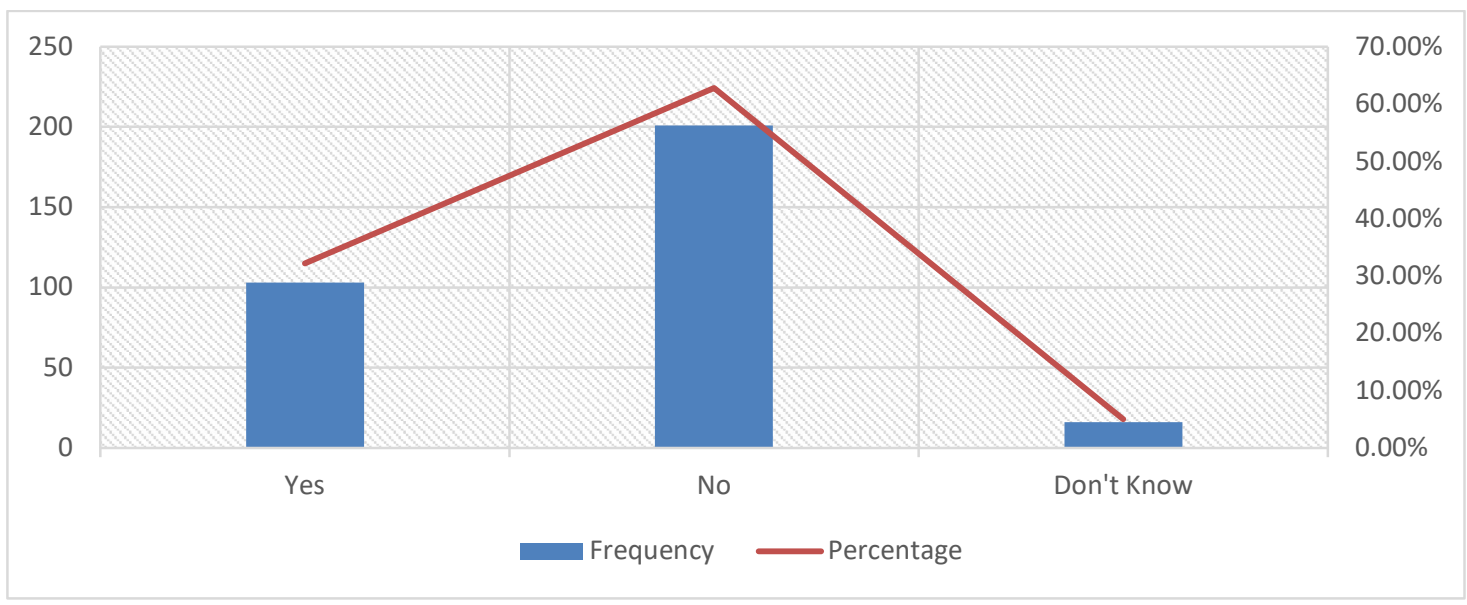

Source: Field Survey

Figure No. 07: Does your university have online library facilities

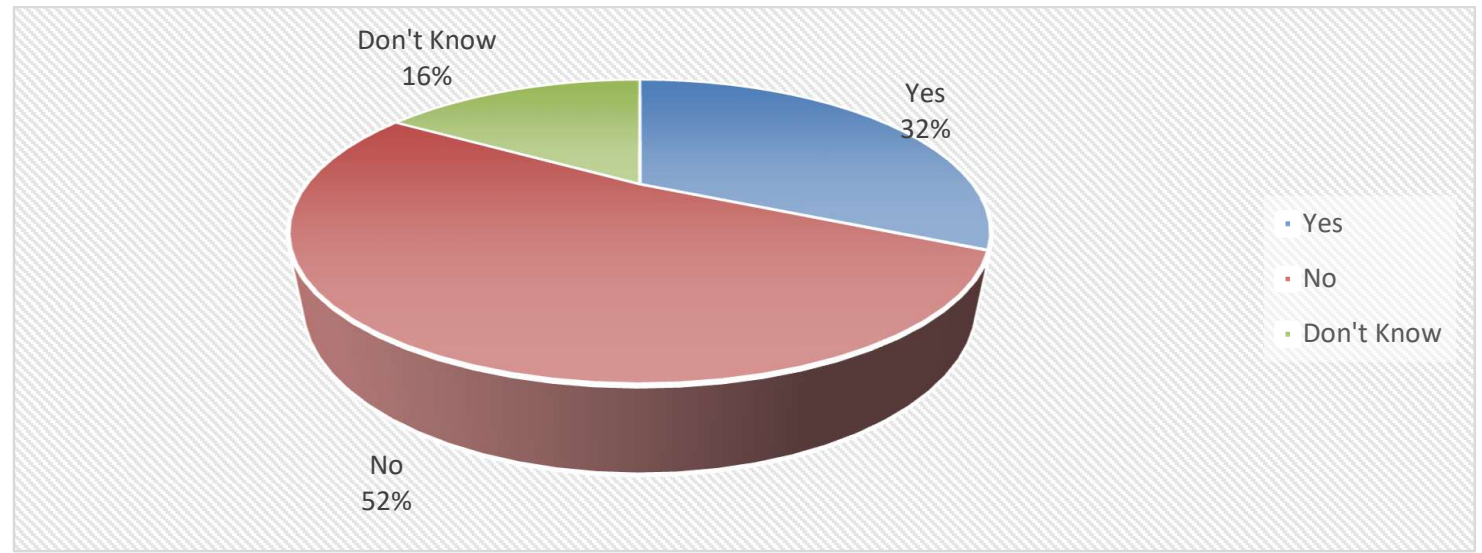

Source: Field Survey 
Figure No. 08: Did you get any training regarding online education from your university?

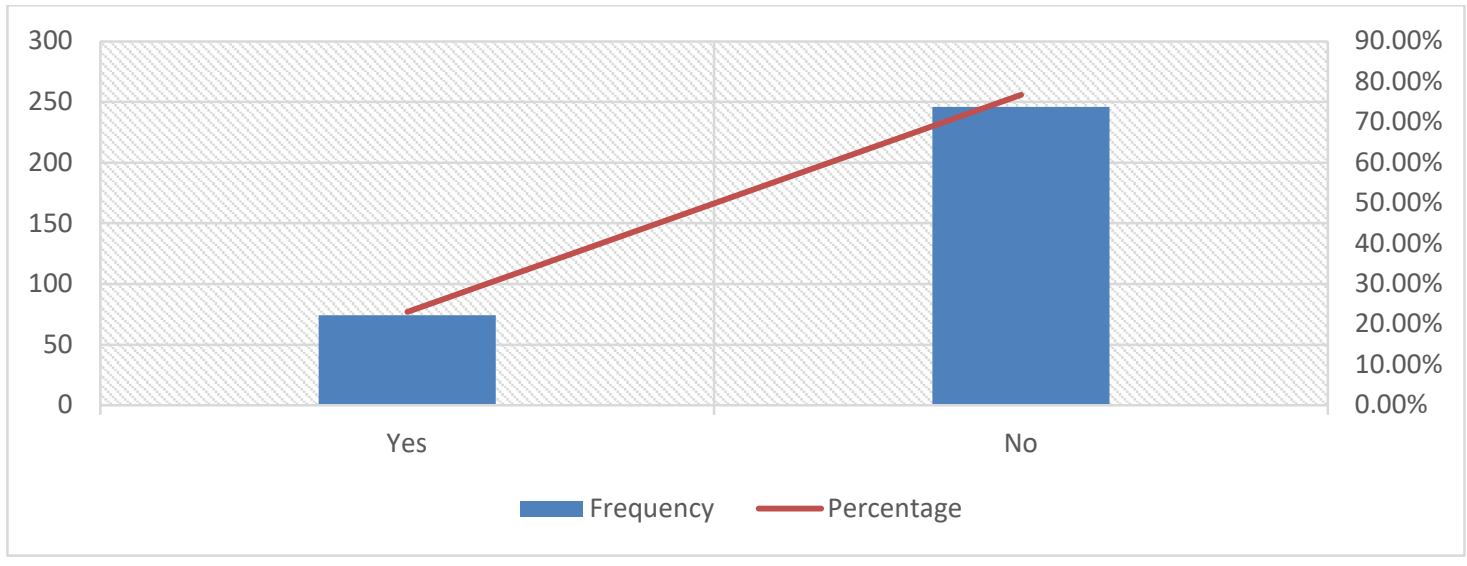

Source: Field Survey

Table No. 06: What are the tools your university encourages to use for online education like Zoom, Google mate, Google classroom, LMS etc.

\begin{tabular}{|l|c|c|c|c|}
\hline Tools & Frequency & Percentage & $\begin{array}{l}\text { Valid } \\
\text { Percent }\end{array}$ & $\begin{array}{l}\text { Cumulative } \\
\text { Percent }\end{array}$ \\
\hline Zoom & 302 & $94.2 \%$ & $94.2 \%$ & $94.2 \%$ \\
\hline Google mate & 4 & $1.2 \%$ & $1.2 \%$ & $95.4 \%$ \\
\hline Google Classroom & 11 & $3.4 \%$ & $3.4 \%$ & $98.8 \%$ \\
\hline Others & 5 & $1.5 \%$ & $1.5 \%$ & $100 \%$ \\
\hline Total & $\mathbf{N}=\mathbf{3 2 0}$ & $\mathbf{1 0 0 \%}$ & $\mathbf{1 0 0} \%$ & \\
\hline
\end{tabular}

Source: Field Survey

\subsubsection{Mentoring:}

Mentoring is a one-on-one relationship in which an experienced person (i.e., a mentor) helps a less experienced colleague (i.e., a protégé or mentee) to advance professionally and personally. (Godshalk and Sosik, 2000; Hegstad, 1999). Mentoring can be an effective tool for reducing the stress that new teachers and students face by providing curriculum orientation and encouraging the development of better collegiality and collaboration standards (Sweeney, 2004). Regarding mentoring, this study asked the respondents two questions, responses are categorized in the following table no. 07 and figure no. 08. Table no 07 shows the responses regarding the statement 'Concerned office or staffs are always taking care of you what you need during covid-19'. In this regard, $50(15.6 \%)$ respondents strongly agreed, $76(23.8 \%)$ agreed, $38(11.8 \%)$ were moderated, 120 (37.5\%) disagreed and $36(11.3 \%)$ strongly disagreed. And figure no 08 represents the data on 'Counseling is continuing during Covid-19'. In this case, $266(83 \%)$ respondents said they are not under counseling. On the other hand, only a few, $18(6 \%)$ said they get such counseling. and the rest $36(11 \%)$ don't know about it. 
Table No. 07: Concerned office or staffs are always taking care of you what you need during covid-19

\begin{tabular}{|l|c|c|c|c|}
\hline Categories & Frequency & Percentage & $\begin{array}{c}\text { Valid } \\
\text { Percent }\end{array}$ & $\begin{array}{c}\text { Cumulative } \\
\text { Percent }\end{array}$ \\
\hline Strongly agree & 50 & $15.6 \%$ & $15.6 \%$ & $15.6 \%$ \\
\hline Agree & 76 & $23.8 \%$ & $23.8 \%$ & $39.4 \%$ \\
\hline Moderate & 38 & $11.8 \%$ & $11.8 \%$ & $51.2 \%$ \\
\hline Disagree & 120 & $37.5 \%$ & $37.5 \%$ & $88.7 \%$ \\
\hline Strongly Disagree & 36 & $11.3 \%$ & $11.3 \%$ & $100 \%$ \\
\hline Total & $\mathbf{N = 3 2 0}$ & $\mathbf{1 0 0 \%}$ & $\mathbf{1 0 0 \%}$ & \\
\hline
\end{tabular}

Source: Field Survey

Figure No. 08: Counselling is continuing during Covid-19

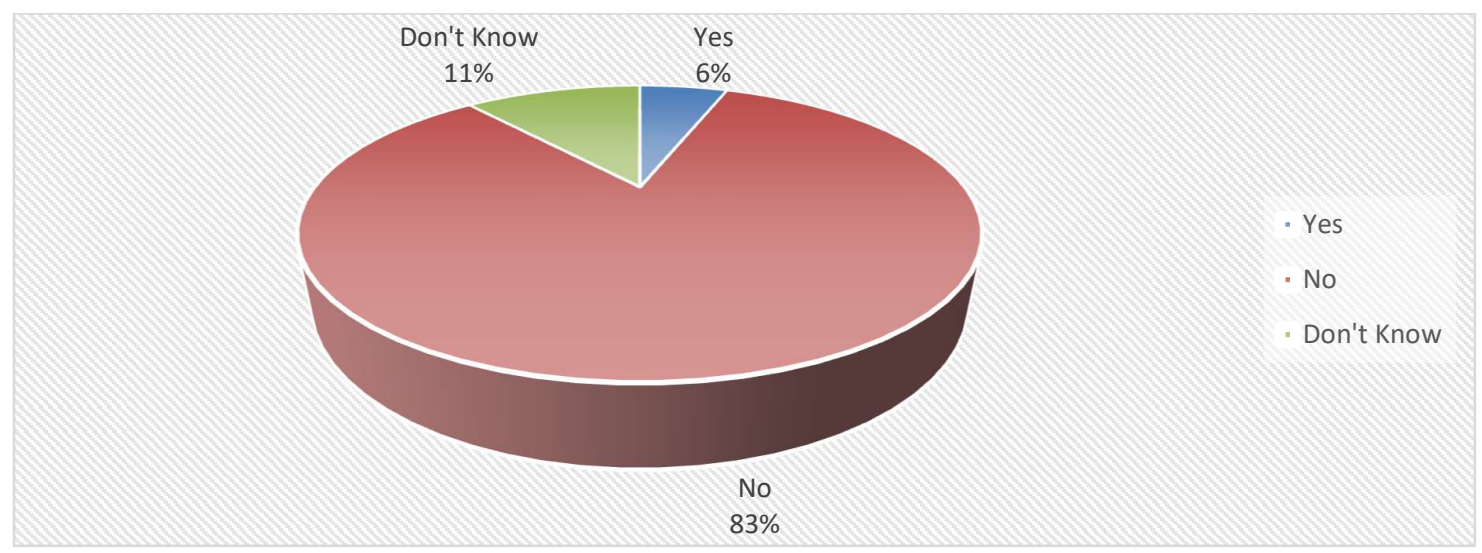

Source: Field Survey

\subsection{General Statements:}

The following table shows the respondent's opinions regarding some statements based on five scales of the Likert scale i.e. strongly agree, Agree, Moderate, Disagree, and Strongly Disagree. The first statement was 'Concerned authorities are supportive in handlings every matter during Covid-19'. Regarding this statement, 10 (3.1\%) respondents strongly agreed, 128 (40\%) agreed, 124 (38.8\%) were moderated, 36 (11.3\%) disagreed and 22 (6.9\%) strongly disagreed. The next statement was 'University have an appropriate environment for online education'. In this case, $20(6.3 \%)$ respondents strongly agreed, $102(31.9 \%)$ agreed, 124 (38.8\%) were moderated, 48 (15\%) disagreed and 26 (8.1\%) strongly disagreed. The next statement was 'Our University has been able to build capacity quickly'. In this context, 42 $(13.1 \%)$ respondents strongly agreed, $34(10.6 \%)$ agreed, $70(21.9 \%)$ were moderated, 162 $(50.6 \%)$ disagreed and $12(3.8 \%)$ strongly disagreed. Regarding this statement 'Feeling Comfortable with the online education', $46(14.4 \%)$ respondents strongly agreed, $82(25.6 \%)$ agreed, 90 (28.1\%) were moderated, $88(27.5 \%)$ disagreed and $54(16.3 \%)$ strongly disagreed. The next statement was 'Online classes are well designed that meets the expectations'; 46 $(14.4 \%)$ respondents strongly agreed, $10(3.1 \%)$ agreed, $90(28.1 \%)$ were moderated, 104 $(32.5 \%)$ disagreed and, $50(15.6 \%)$ strongly disagreed. Regarding this statement- 'Instructors 
are using a different method in conducting online classes that meet the gap', $20(6.3 \%)$ respondents strongly agreed, $72(22.5 \%)$ agreed, 88 (27.5\%) were moderated, $86(26.9 \%)$ disagreed and $54(16.9 \%)$ strongly disagreed. The last statement was 'Online Classes are very effective for teaching-learning processes'. In this regard, $8(5 \%)$ respondents strongly agreed, $56(17.5 \%)$ agreed, $78(24.4 \%)$ were moderated, $100(31.3 \%)$ disagreed and $70(21.9 \%)$ strongly disagreed.

Table: Some general Statements regarding Institutional Support

\begin{tabular}{|c|c|c|c|c|c|}
\hline General Statements & 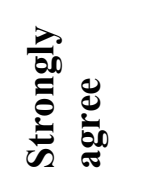 & 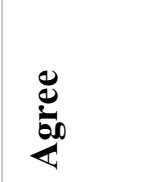 & 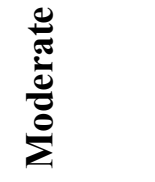 & 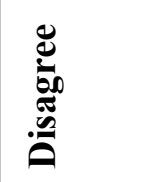 & 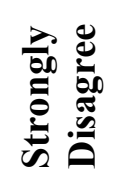 \\
\hline $\begin{array}{l}\text { Concerned authorities are supportive in } \\
\text { handlings every matters during Covid- } \\
19\end{array}$ & $\begin{array}{c}10 \\
(3.1 \%)\end{array}$ & $\begin{array}{c}128 \\
(40 \%)\end{array}$ & $\begin{array}{c}124 \\
(38.8 \%)\end{array}$ & $\begin{array}{c}36 \\
(11.3 \%)\end{array}$ & $\begin{array}{c}22 \\
(6.9 \%)\end{array}$ \\
\hline $\begin{array}{l}\text { University have an appropriate } \\
\text { environment for online education }\end{array}$ & $\begin{array}{l}20 \\
(6.3 \%)\end{array}$ & $\begin{array}{l}102 \\
(31.9 \%)\end{array}$ & $\begin{array}{l}124 \\
(38.8 \%)\end{array}$ & $\begin{array}{l}48 \\
(15 \%)\end{array}$ & $\begin{array}{l}26 \\
(8.1 \%)\end{array}$ \\
\hline $\begin{array}{l}\text { Our university has been able to build } \\
\text { capacity quickly }\end{array}$ & $\begin{array}{l}42 \\
(13.1 \%)\end{array}$ & $\begin{array}{l}34 \\
(10.6 \%)\end{array}$ & $\begin{array}{l}70 \\
(21.9 \%)\end{array}$ & $\begin{array}{l}162 \\
(50.6 \%)\end{array}$ & $\begin{array}{l}12 \\
(3.8 \%)\end{array}$ \\
\hline $\begin{array}{l}\text { Feeling Comfortable with the online } \\
\text { education }\end{array}$ & $\begin{array}{l}46 \\
(14.4 \%)\end{array}$ & $\begin{array}{l}82 \\
(25.6 \%)\end{array}$ & $\begin{array}{l}90 \\
(28.1 \%)\end{array}$ & $\begin{array}{l}88 \\
(27.5 \%)\end{array}$ & $\begin{array}{l}54 \\
(16.3 \%)\end{array}$ \\
\hline $\begin{array}{l}\text { Online classes are well designed that } \\
\text { meets the expectations }\end{array}$ & $\begin{array}{l}10 \\
(3.1 \%)\end{array}$ & $\begin{array}{l}66 \\
(20.6 \%)\end{array}$ & $\begin{array}{l}90 \\
(28.1)\end{array}$ & $\begin{array}{l}104 \\
(32.5 \%)\end{array}$ & $\begin{array}{l}50 \\
(15.6 \%)\end{array}$ \\
\hline $\begin{array}{l}\text { Instructors are using a different method } \\
\text { in conducting online classes that meet } \\
\text { the gap }\end{array}$ & $\begin{array}{l}20 \\
(6.3 \%)\end{array}$ & $\begin{array}{l}72 \\
(22.5 \%)\end{array}$ & $\begin{array}{l}88 \\
(27.5 \%)\end{array}$ & $\begin{array}{l}86 \\
(26.9 \%)\end{array}$ & $\begin{array}{l}54 \\
(16.9 \%)\end{array}$ \\
\hline $\begin{array}{l}\text { Online Classes are very effective for } \\
\text { the teaching-learning process }\end{array}$ & $\begin{array}{l}8 \\
(5 \%)\end{array}$ & $\begin{array}{l}56 \\
(17.5 \%)\end{array}$ & $\begin{array}{l}78 \\
(24.4 \%)\end{array}$ & $\begin{array}{l}100 \\
(31.3 \%)\end{array}$ & $\begin{array}{l}70 \\
(21.9 \%)\end{array}$ \\
\hline
\end{tabular}

Source: Field Survey

\section{Discussion:}

As it is mentioned earlier that covid-19 has forced the academic activities of Bangladesh to shift to online. This study finds that most of the respondents are taking part in online classes. Out of 320 respondents, $308(96.30 \%)$ are active in online education but they (148) are marginally happy with their online education except very few. There is a significant gap between physical education and online education and online never be a replacement for physical one. $244(76.30 \%)$ respondents said online classes do not meet the needs and demands of quality education. This study is based on major three principles of the Adapted Model of Institutional Support (AMIS) and Valverde and Rodriguez's 2002's Institutional Support Model (ISM) models. Regarding financial assistance, most of the respondents, $266(83.1 \%)$ said that their university provides average financial assistance for meeting the gap during covid-19. And this assistance did not cover all the stakeholders. Some of the universities reduced their semester fees and others did not where a student faces huge financial crisis during the pandemic. Regarding technical assistance, most of the universities in Bangladesh do not have online library facilities. $166(52 \%)$ respondents said that their universities do not have online library facilities and they did not get any training or grooming session that would have been helpful. But a number of respondents got such training session also. The online classes are continued through zoom apps in most of the universities of Bangladesh as $302(94.2 \%)$ of respondents used it. Mentoring is one of the significant processes by which participants reduces 
stress and pressures. It is highly recommended during such pandemics. Regarding this, 120 $(37.5 \%)$ respondents said that concerned office or staffs are not enough taking care of you what they need during covid-19. Finally, it is observed that an average institutional supports have been provided to the stakeholders as it was not sufficient.

\section{Conclusion and Recommendation:}

Academic programs have been severely interrupted, and students are extremely depressed as they consider their academic future in the aftermath of the COVID-19 lockout. The study's main goal is to assess Bangladesh's institutional support for online education in the midst of a pandemic. While the government, the University Grants Commission, colleges, and many other institutions have taken measures to support online education, this study finds that their support and planning are insufficient to reduce this massive academic loss. In light of this, the authors of this study advise authorities and policymakers to take the following steps.

- Firstly, in all universities and colleges, dedicated software can be set up for ongoing learning tasks such as holding classes, taking attendance, examinations, tests, and evaluations.

- Secondly, more training and grooming sessions for both teachers and students, as well as staff, should be organized, as many senior professors are unfamiliar with modern technologies.

- Thirdly, the authorities should take measures to ensure stronger, more reliable internet service at affordable rates, given that the majority of students attend online classes from rural areas and $68.9 \%$ of students rely on mobile internet. Academic institutions along with UGC and other private sectors should take the responsibilities for ensuring such an environment at any cost.

- Fourthly, along with online classes, online mentoring and counseling sessions should be made available to ensure that students of all ages and teachers receive mental support and that learning does not become monotonous.

- Lastly, successfully identifying potential flaws and roadblocks that students may face, as well as providing appropriate solutions. Instructors, for example, must be creative in assessing students' class performance and keeping them engaged throughout the class by employing a variety of teaching techniques.

\section{References:}

Abdullah, M., (2020) 'The rise of online education', retrieved from Dhaka tribune, 31st December, 2020, adapted from https://www.dhakatribune.com/bangladesh/2020/12/31/2020-rise-of-online-education accessed on 17 march 2021.

Al-Amin, M., Zubayer, A., Deb, B., and Hasan, M., (2021), 'Status of tertiary level online class in Bangladesh: students' response on preparedness, participation and classroom activities', Elsevier Ltd, Heliyon, 7 (2021) e05943.

Alamgir, M., (2020), 'Cost of Online Classes: Extra burden on parents, teachers', retrieved from the daily star, adapted from https://www.thedailystar.net/frontpage/news/costonline-classes-extra-burden-parents-teachers-1935773 accessed on 11 January 2021. 
Al-Enazi, G. T., (2016), 'Institutional Support for Academic Stato Adopt Virtual Learning Environments (VLEs) in Saudi Arabian Universities', Durham University, Durham theses (2016), Available at Durham E-Theses.

Bangert, A., W., (2006), 'Identifying factors underlying the quality of online teaching effectiveness: An exploratory study', Journal of Computing in Higher Education, 17(2), 79-99.

Battistich, V., Solomon, D., \& Kim, D. (1995), 'Schools as communities, poverty levels of student populations, and students' attitudes, motives, and performance', American Educational Research Journal, 32, 627-658.

Bennett, C. F., \& Monds, K. E., (2008), 'Online courses the real challenge is motivation', College Teaching Methods \& Styles Journal (CTMS), 4(6), 1-6.

Bond, M., L., Cason, C., L, and Gray, J., R., (2015), 'the adapted model of institutional support for Hispanic student degree completion: revisions and recommendations', Hisp Health Care Int. 13(1):38-45. doi: 10.1891/1540-4153.13.1.38. PMID: 25741932.

Bottiani, J. H., Bradshaw, C. P., \& Mendelson, T., (2016), 'Inequality in Black and White high school students' perceptions of school support: An examination of race in context', Journal of Youth and Adolescence, 45(6), 1176-1191.

Cornell, D., Shukla, K., \& Konold, T. R., (2016), 'Authoritative school climate and student academic engagement, grades, and aspirations in middle and high schools', AERA Open, 2(2), 1-18. doi: 10.1177/2332858416633184.

Dhaka tribune, (2020), 'The rise of online education', retrieved on $31^{\text {st }}$ December, 2020, https:/www.dhakatribune.com/bangladesh/2020/12/31/2020-rise-of-online-education accessed on 17 march 2021.

Godshalk, V. M., \& Sosik, J. J., (2000), 'Does mentor-protégé agreement on mentor leadership behavior influence the quality of amentoring relationship?' Group \& Organization Management, 25, 291-317.

Gorsky, P., \& Blau, I., (2009), 'Online teaching effectiveness: A tale of two instructors', The International Review of Research in Open and Distributed Learning, 10 (3).

Gottfredson, L., S. (1996), 'Gottfredson's theory of circumscription and compromise', In D. Brown, L. Brooks, \& Associates (Eds.), 'Career choice and development' (3rd ed., pp. 179- 232).San Francisco, CA: Jossey-Bass.

Gottfredson, L., S. (2002), 'Gottfredson's theory of circumscription, compromise, and selfcreation, San Francisco, CA: Jossey-Bass

Hegstad, C. D., (1999), 'Formal mentoring as a strategy for human resource development: A review of research', Human Resource Development Quarterly, 10(1), 383-391.

Islam, M. S., Tanvir, K. M., Amin, M., and Salman, M., (2020), 'Online Classes for university Students in Bangladesh during the Covid-19 Pandemic- Is it Feasible?' Retrieved 20 August, 2020 from: https://tbsnews.net/thoughts/online-classes-universi Accessed on 23 march 2021.

Jasim, M. M., (2020), 'Private university students taking online classes', Retrieved from https://tbsnews.net/coronavirus-chronicle/covid-19-bangladesh/private-universitystudents-taking-online-classes-64867 Accesses on 3 march 2021. 
Kotok, S., Ikoma, S., \& Bodovski, K., (2016), 'School climate and dropping out of school in the era of accountability', American Journal of Education, 122(4), 569-599.

Lavy, V., (2002), 'Evaluating the Effect of Teachers' Group Performance Incentives on Pupil Achievement', Journal of Political Economy, 110(6), 1286-1317.

Moralista, R., \& Oducado, R. M., (2020), 'Faculty Perception toward Online Education in a State College in the Philippines during the Coronavirus Disease 19 (COVID-19) Pandemic', Universal Journal of Educational Research, 8(10), 4736-4742. https://doi.org/10.13189/ujer.2020.081044

Muilenburg, L. Y., \& Berge, Z. L., (2005), 'Student barriers to online learning: A factor analytic study’, Distance education, 26(1), 29-48.

OECD, (2008), 'Tertiary Education for the Knowledge Society', Background reports prepared by 21 countries, Reviews of Tertiary Education in 14 countries and other documents of the review are also available on the OECD website www.oecd.org/edu/tertiary/review

Panday, P. K., (2020), 'Online Classes and Lack of Interactiveness', Retrieved on 20 August, 2020 from: https://www.daily-sun.com/printversion/details/502935 Accessed on 17 December 2021.

Rahman, N., E., (2020), 'Online education during COVID-19: Prospects, challenges and way forward', The Independent, Retrieved on 11 November 2020 from http://www.theindependentbd.com/post/254623 Accessed on 15 January 2021.

Saint, W., Harnett, T., A., and Strassner, E., (2003), 'Higher education in Nigeria: a status report', High Educ. Pol., 16 (2003), pp. 259-281.

Schrum, L., \& Hong, S. (2002), 'Dimensions and strategies for online success: Voices from experienced educators', Journal of Asynchronous Learning Networks, 6(1), 57-67.

Sife, A. S., Lwoga, E. T. \& Sanga, C. (2007), 'New technologies for teaching and learning: Challenges for higher learning institutions in developing countries', International Journal of Education and Development using ICT, 3(1). Retrieved July 21, from http://ijedict.dec.uwi.edu//.

Sirkemaa, S., (2001), 'Information technology in developing a meta-learning environment', European Journal of Open, Distance and E-Learning. Retrieved April 10, 2007, from http://www.eurodl.org/.

Sujan, S., (2020), ‘63 universities taking online classes, 70\% students', Bonik Barta, Retrieved from https://bonikbarta.net/home/news_description/228213 Accessed on 16 March 2021.

Sweeney, B., (2004), 'Ask the mentor of mentors: a collection of answers to frequently asked questions’. http://teachermentors.com/RSOD\%20Site/AskMOM.html.

Tabassum, M., Mannan, S., E., Parvej, M. I., and Ahmed, F., (2021), 'Online Education during COVID-19 in Bangladesh: University Teachers' Perspective', Aquademia, 5(1), ep21005. https://doi.org/10.21601/aquademia/9611

Tariq, S. B., Fami, T., (2020), 'Is Online Education System Suitable for Bangladesh?' Retrieved on 20 August, 2020, Adapted from: https://tbsnews.net/thoughts/onlineeducatio n-system-suitable-bangladesh-112546 Accessed on February 21, 2021. 
Valdez, G., Fulton, K., Glenn, A., Wimmer, N. A. \& Blomeyer, R. (2004), 'Effective Technology Integration in Teacher Education: A Comparative Study of Six Programs', Innovate Journal of Online Education, 1(1). Retrieved April 10, 2007, from http://Innovateonline.info

Valverde, M., and Rodriguez, R., (2002), 'Increasing Mexican American Doctoral Degrees: The Role of Institutions of Higher Education', Sociology, Journal of Hispanic Higher Education, vol, 1, 51-58. 